\title{
Ectodermal dysplasias: a new clinical-genetic classification
}

\author{
Manuela Priolo, Carmelo Laganà
}

\begin{abstract}
The ectodermal dysplasias (EDs) are a large and complex nosological group of diseases, first described by Thurnam in 1848. In the last 10 years more than 170 different pathological clinical conditions have been recognised and defined as EDs, all sharing in common anomalies of the hair, teeth, nails, and sweat glands. Many are associated with anomalies in other organs and systems and, in some conditions, with mental retardation.

The anomalies affecting the epidermis and epidermal appendages are extremely variable and clinical overlap is present among the majority of EDs. Most EDs are defined by particular clinical signs (for example, eyelid adhesion in AEC syndrome, ectrodactyly in EEC). To date, few causative genes have been identified for these diseases.

We recently reviewed genes known to be responsible for EDs in light of their molecular and biological function and proposed a new approach to EDs, integrating both molecular-genetic data and corresponding clinical findings. Based on our previous report, we now propose a clinical-genetic classification of EDs, expand it to other entities in which no causative genes have been identified based on the phenotype, and speculate on possible candidate genes suggested by associated "non-ectodermal" features.

(F Med Genet 2001;38:579-585)
\end{abstract}

Keywords: ectodermal dysplasia; clinical-functional correlation; epithelial-mesenchymal interaction; ectodermal structural proteins

More than 170 different pathological conditions have been reported as ectodermal dysplasias, ${ }^{1-3}$ which are often associated with anomalies of other organs and systems including mental retardation. ${ }^{4-8}$ The anomalies affecting the epidermis and epidermal appendages are very variable. ${ }^{9} 10$

Operative Unit of Medical Genetics, Azienda Ospedaliera Bianchi-MelacrinoMorelli, Via

Melacrino, 89100

Reggio Calabria, Italy

M Priolo

C Laganà

Correspondence to:

DrPriolo, prioloma@libero.it
Previous classification

Pinheiro and Freire-Maia ${ }^{2}$ extensively reviewed EDs. They defined as ED any condition in which defects in two or more ectodermal derivatives are present. They classified the conditions according to the ectodermal structures involved and gave a number to each ectodermal derivative (hair is 1 , teeth are 2 , nails are 3 , sweat gland function is 4 ); they identified 10 different subgroups for the EDs (for example, 1-2-3-4, 1-2-3). They included many case reports and personal communications in their listing of EDs, as well as conditions traditionally classified under other headings, for example dyskeratosis congenita ${ }^{11}$ and keratitis-ichthyosis-deafness (KID) syndrome $^{12}$ (poikiloderma and immune defect diseases and erythrokeratodermas, respectively). Further, they did not appear to consider variability of expression and may have reported, as distinct diseases, conditions that reflect variable expression of the same pathological entity. Moreover, they included pathological conditions which, in our opinion, do not strictly fulfil the diagnostic criteria for EDs, such as conditions with secondary involvement of epidermal derivatives rather than a primary defect. We abandoned the 1-23-4 designation of EDs, because we believe that variable expression can render it misleading. ${ }^{3}$ The numerical system is difficult to remember and cumbersome to use.

\section{Proposed classification}

In light of what is currently known about the molecular basis and biological functions in EDs, we propose a new classification which is an attempt to integrate both molecular-genetic data and corresponding clinical findings. We basically propose two different groups, each likely to result from mutations in genes with similar function and possibly involved in the same mechanisms of regulation of development and/or pathogenesis (table 1).

\section{Materials and methods}

We decided only to consider those pathological conditions cited in the last revision of Pinheiro and Freire-Maia ${ }^{2}$ and also listed as OMIM (Online Mendelian Inheritance in Man) entries. We reviewed these conditions using ENTREZ in $\mathrm{OMIM}^{13}$ and searching for respective OMIM numbers. We also included five new entries obtained from ENTREZ in $\mathrm{OMIM}^{13}$ using the search term "ectodermal dysplasia", which were not included in the classification of Pinheiro and Freire-Maia.

INCLUSION/EXCLUSION CRITERIA

We strictly limited inclusion to those conditions with primary defects in at least two of the following ectodermal derivatives: hair, teeth, nails, and sweat gland function. Disorders that were reported in a single case or by personal communication were excluded, as their validity cannot be assessed and inheritance could not be established. Similarly, we did not include syndromes that have traditionally been classified under other rubrics. For example, in cardiofaciocutaneous (CFC) syndrome, hair anomalies and ulerythema ophryogenes are 
Table 1 Classification scheme of EDs. Italic bold entries indicate identified causative gene; Mendelian inheritance is also reported

\begin{tabular}{|c|c|c|c|}
\hline \multirow{20}{*}{$\begin{array}{l}\text { Look at TNF-like TNFRs } \\
\text { signalling pathways/NF-kB } \\
\text { regulation patterns if: }\end{array}$} & Major ectodermal derivative & 1 & Hypohidrotic ED, X linked (MIM 305100) \\
\hline & involvement & 2 & Hypohidrotic ED, (MIM 129490) \\
\hline & & & Hypohidrotic ED, (MIM 224900) \\
\hline & & 3 & Dermo-odonto dysplasia (MIM 125640) \\
\hline & & 4 & Hidrotic ED (Christianson Fourier type) (MIM 601375) \\
\hline & & 5 & $\begin{array}{l}\text { Odonto-onycho-ungual-digito-palmar syndrome, Mendoza-Valiente type (MIM } \\
601957 \text { ) }\end{array}$ \\
\hline & & 6 & Amelo-onycho-hypohidrotic sindrome (MIM 104570) \\
\hline & & 7 & BOOK syndrome (canities prematura) (MIM 112300) \\
\hline & & 8 & Pili torti (twisted hair) with enamel defects (MIM 261900) \\
\hline & & 9 & Hypodontia-nail dysgenesis “tooth-nail syndrome” (MIM 189500) \\
\hline & & 10 & Taurodontia, absent teeth, and sparse hair (MIM 272980) \\
\hline & & 11 & Odonto-onycho-hypohidrotic dysplasia with midline scalp defects (MIM 129550) \\
\hline & & 12 & Scalp/ear/nipple syndrome (MIM 181270) \\
\hline & & 13 & Ectodermal dysplasia with natal teeth, Turnpenny type (MIM 601345) \\
\hline & & 14 & Ectodermal dysplasia, “pure” hair-nail type (MIM 602032) \\
\hline & ID, abnormal immune response, & 15 & IP (MIM 308310) \\
\hline & functional abnormalities of $C N S$ & 16 & $H E D-I D$ and XHM-ED (MIM 300291) \\
\hline & & 17 & Onycho-tricho-dysplasia and neutropenia (MIM 258360) \\
\hline & & 18 & Amelo-cerebro-hypohidrotic syndrome (epilepsy and yellow teeth) (MIM 226750) \\
\hline & & 19 & Cerebellar ataxia and ectodermal dysplasia (MIM 212835) \\
\hline \multirow{16}{*}{$\begin{array}{l}\text { Look at regulators of gene } \\
\text { expression if: }\end{array}$} & Major skeletal involvement & 20 & EEC syndrome (EEC3) (MIM 604292) \\
\hline & & & AEC syndrome (MIM 106260) \\
\hline & & & Rapp-Hodgkin (MIM 129400) \\
\hline & & & ADULT syndrome (MIM 103285) \\
\hline & & 21 & EEC syndrome (EEC1) (MIM 129900) \\
\hline & & 22 & TDO syndrome (MIM 190320) \\
\hline & & 23 & EvC syndrome (MIM 225500) \\
\hline & & 24 & Limb-mammary syndrome (MIM 603543) \\
\hline & & 25 & LADD syndrome ( MIM 149730) \\
\hline & & 26 & Cartilage-hair hypoplasia (MIM 250250) \\
\hline & & 27 & Sensenbrenner disease (cranio-ectodermal dysplasia) (MIM 218330) \\
\hline & & 28 & $\begin{array}{l}\text { Tricho-odonto-onychial-dysplasia with bone deficiency in frontoparietal region } \\
\text { (MIM 275450) }\end{array}$ \\
\hline & & 29 & ACD syndrome (MIM 203550) \\
\hline & & 30 & Odonto-trichomelic syndrome (MIM 273400) and (MIM 273390) \\
\hline & Endocrine defects & 31 & CLPED/Fryns-Soekerman type (MIM 225040) \\
\hline & & 32 & ANOTHER syndrome (MIM 225050) \\
\hline \multicolumn{4}{|c|}{ Group 2 (Cytoskeleton maintainance and cell stability) } \\
\hline \multirow{7}{*}{$\begin{array}{l}\text { Look at connexins, desmosomal } \\
\text { plaques, proteins if: }\end{array}$} & Hyperkeratosis/ keratoderma & 1 & Clouston disease (MIM 129500) \\
\hline & & 2 & ED/skin fragility syndrome (MIM 604536) \\
\hline & & 3 & Odonto-onycho-dermal-dysplasia (MIM 257980) \\
\hline & & 4 & $\begin{array}{l}\text { Leucomelanoderma, infantilism, mental retardation, hypodontia, hypotrichosis } \\
\text { (MIM 246500) }\end{array}$ \\
\hline & & 5 & Naegeli-Franceschetti-Jadassohn syndrome (MIM 161000) \\
\hline & & 6 & Amelo-onycho-hypohidrotic syndrome (MIM 104570) \\
\hline & & 7 & Pilodental dysplasia with refractive errors (MIM 262020) \\
\hline \multirow{3}{*}{ Look at connexins if: } & Deafness, and/or corneal anomalies & 8 & Deafness-onychodystrophy (MIM 124480) \\
\hline & & 9 & Deafness, enamel hypoplasia, and nail defects (MIM 234580) \\
\hline & & 10 & ED, tricho-odonto-onychial and amastia (MIM 129510) \\
\hline \multirow[t]{2}{*}{ Look at NAP system proteins if: } & $C L P E D$ & 11 & Zlogotora-Ogur/Rosselli-Guglielmetti syndrome (MIM 225000) \\
\hline & & & ED Margarita type syndrome (MIM 225060) \\
\hline \multirow[t]{3}{*}{ Look at PDZ proteins if: } & Retinal degeneration & 12 & Oculo-tricho-dysplasia (MIM 257960) \\
\hline & & 13 & Bork syndrome (MIM 191482) \\
\hline & & 14 & EEM syndrome (MIM 225280) \\
\hline
\end{tabular}

seen, ${ }^{14}$ but the ectodermal alterations are minor features. We did not include those pathological conditions with secondary involvement of epidermal derivatives probably resulting from a different primary defect and have classified them as "secondary EDs" (for example, Rothmund-Thomson syndrome, ${ }^{15}$ trichothiodystrophies, ${ }^{16}$ and dyskeratosis congenita ${ }^{11}$ ).

\section{GROUPING CRITERIA}

We decided to consider first the underlying functional defect and then to try to integrate data from the clinical presentation of the related diseases. This approach is a first attempt at integration of both systems of classification and, in some ways, it may be criticised, especially when simply basing it on clinical presentation of diseases, focusing on "non-ectodermal features", and trying to hypothesise about a possible causative gene, we arbitrarily decided to include one specific ED in one group rather than another. Nonetheless, our goal is to give both clinicians and researchers a "key" to better understanding the wide clinical variability in presentation of EDs and in dissecting "complicated" phenotypes characterised by overlap between different kinds of EDs. In the same way, we believe that this approach may help to find new candidate genes.

\section{Group 1}

The first group includes disorders in which a defect in developmental regulation and in epithelial-mesenchymal interaction can be recognised or hypothesised on the basis of an identified causative gene, its putative or proven function, and pattern of expression. There is considerable heterogeneity in clinical presentation.

The EDs included may be characterised by major ectodermal derivatives involvement. X linked anhidrotic ectodermal dysplasia (XEDA) is the most common type of $\mathrm{ED}^{17}$ and clinically similar EDA may be inherited as autosomal dominant or autosomal recessive conditions. ${ }^{18} 19$ These are much rarer than the $\mathrm{X}$ linked form. All these forms are clinically indistinguishable. An altered immune response or immunodeficiency can be observed as a 
major clinical sign. Incontinentia pigmenti (IP) (MIM 303810), hypohidrotic ectodermal dysplasia with immunodeficiency (EDA-ID) (MIM 300291), and a newly recognised syndrome of EDA-ID with osteopetrosis and lymphoedema (OL-EDA-ID) are three conditions in this group for which a common causative gene has been identified. ${ }^{20-22}$ We included in this group other EDs with no causative gene identified in which major ectodermal derivative involvement, immunodeficiency, or functional abnormalities of the central nervous system are present. We believe that a specific functional pattern is likely to be altered in the pathogenesis of these kinds of disease.

EDs characterised by major skeletal involvement are included in this category as well. Ectrodactyly-ectodermal dysplasia-cleft lip/ palate (EEC) (MIM 604292), ankyloblepharonectodermal dysplasia-cleft lip/palate (AEC) (MIM 106260), acro-dermato-ungual-lacrimaltooth (ADULT) (MIM 103285), tricho-dentoosseous (TDO) (MIM 190320), and Ellis-van Creveld (EvC) (MIM 225500) syndromes are included and their causative genes have been identified. ${ }^{23-26}$ Finally, we included EDs with endocrine defects. Hypothyroidism is frequently reported in association with EDs, for example, CLPED/Fryns-Soekerman type (MIM 225040) and ANOTHER syndrome (MIM 225050). ${ }^{27} 28$ In these cases, we think that the defect in epithelial-mesenchymal interaction is likely to be caused through a different functional pattern of signalling and that candidate genes are to be searched for among nuclear proteins such as transcription factors or among regulators of gene expression.

BIOLOGICAL-FUNCTIONAL FEATURES AND IDENTIFIED CAUSATIVE GENES

An altered epithelial-mesenchymal interaction seems to be one of the most important mechanisms in the pathogenesis of EDs. During the development of skin appendages, epithelium and mesenchyme are inducers and targets of each other. ${ }^{3}$ Secreted signal molecules transmit sequential and reciprocal inductive interactions between these two structures. The interaction between ectoderm and mesoderm is sustained by the expression of specific proteins which act through different morphogenetic signalling pathways. ${ }^{3}$ Basically, two functional patterns of regulation of this interaction have been identified and recognised as possible pathogenetic mechanisms in EDs so far.

The epithelial-mesenchymal interaction may be altered if the nuclear factor kappa beta $(\mathrm{NF}-\mathrm{kB})$ regulation pattern, acting through different signalling pathways, is involved. The ectodysplasin gene isoform $\mathrm{A} 1(E D A-A 1)$ is mutated in $\mathrm{X}$ linked EDA. ${ }^{29}$ The $D L$ gene is mutated in autosomal dominant EDA and in some patients with an autosomal recessive form of EDA. ${ }^{30}$ The same clinical expression is caused by different mutations in two genes whose products physically interact with each other in a receptor ligand system. ${ }^{30}{ }^{31}$ In other families with autosomal recessive EDA, linkage to the $D L$ locus has been excluded. ${ }^{30}$ Other causative genes probably involve the same mechanism of signal transduction beyond the EDA-A1/DL binding complex, resulting in an EDA phenotype. $E D A-A 1$ and $D L$ are two members of the tumour necrosis factor-like (TNF-like) ligand family and the tumour necrosis factor receptor (TNFR) superfamily genes, respectively. ${ }^{31}{ }^{32}$ In the mouse, the Tabby (Ta) gene is homologous with human $E D A .^{33}$ Its protein product is ectodysplasin. The expression of Ta in several epithelial cell lines did not result in prominent changes in cell morphology and did not promote apoptosis, as expected of TNF-like proteins, which are critically involved in cell survival and apoptosis. On the other hand, this protein promotes cell adhesion, a function consistent with its postulated role in the epithelial-mesenchymal interface, in cell-matrix interaction, and in regulation of the development of ectodermal appendages. ${ }^{34}$ The EDA-A1/DL binding complex seems to regulate $\mathrm{NF}-\mathrm{kB}$ action by enhancing the latter's activity through a specific novel signalling pathway. ${ }^{35}$ Recent findings have shown that DL triggers NF-kB through NEMO protein. ${ }^{22}$ The NEMO gene has been found to be deleted in many cases of familial $\mathrm{IP}^{20}$ It encodes a protein whose activity is to modulate expression of NF-kB factor. ${ }^{36}$ This action eventually regulates the expression of genes controlling apoptosis. Cells from IP patients have been found to have extreme susceptibility to apoptosis, while, clinically, IP patients may present an abnormal immune response. NEMO exon 10 mutations have been found to cause another X linked EDA with immunodeficiency (EDA-ID). ${ }^{21}$ Similarly, NEMO is mutated in patients affected with OL-EDA-ID. ${ }^{22}$ IP, EDA-ID, and OL-EDA-ID are allelic diseases with a clear genotypephenotype correlation, loss of function mutations (large deletions) determining $\mathrm{X}$ linked dominant IP and hypomorphic mutations (stop codon mutation) causing $\mathrm{X}$ linked recessive OL-EDA-ID. ${ }^{22}$ Patients affected with EDA-ID carry mutations in the NEMO coding region, further indicating a genotypephenotype correlation among patients with NEMO mutations. These mutations probably exert a different, milder effect than the stop codon mutation, and this would explain why EDA-ID patients have a milder clinical phenotype than OL-EDA-ID patients. ${ }^{22}$ In EDA-ID patients a residual activity of EDA-A1/DL complex is likely to exist, and this could explain the milder EDA phenotype with regard to EDA-A1/DL patients. Finally, the NEMO gene is also mutated in a peculiar hypohidrotic ectodermal dysplasia with immunodeficiency characterised by hyper $\operatorname{IgM} .{ }^{37}$ On the basis of these results, NEMO would be a reasonable candidate gene for other EDs with immunodeficiency such as onycho-tricho dysplasia with neutropenia (MIM 258360).

A defect in epithelial-mesenchymal interaction is also observed when some regulators of transcription and/or expression of genes with functions in signalling between ectoderm and mesenchyme are mutated. p63 and DLX3 proteins are two transcription factors mutated in some cases of EEC and AEC syndrome 
$(\mathrm{p} 63)^{2324}$ and TDO syndrome (DLX3). ${ }^{25}$ These proteins influence the transcription of specific target genes by binding to cis acting elements located in their regulatory regions. ${ }^{3}$ The EVC gene is mutated in some patients affected with Ellis-van Creveld syndrome. ${ }^{26}$ The function of EVC is not known, but, as previously shown for p63 and DLX3, it may also act as a regulating factor expressed in very early stages of development and may be essential for signalling pathways between ectoderm and mesenchyme. ${ }^{26}$ Its action may differentially regulate or be regulated by the expression of another gene, the collapsin response mediator protein-1 (CRMP1) (MIM 602462) located at the 3 ' end of $E V C$ and presenting a tail-tail homology with the $E V C$ gene. ${ }^{38}$ A sort of "reciprocal" sequestering of both EVC and CRMP1 at different stages of development has been proposed as one of the mechanisms of this regulation.

\section{Group 2}

The second group includes disorders in which a structural protein defect has been found or can be inferred by specific clinical features. Group 2 EDs are characterised by heterogeneous clinical findings. Major clinical signs are hyperkeratosis, as in Clouston disease (MIM 129500), ${ }^{39}$ deafness, cleft lip/palate (CLP), as in CLPED1 syndromes (Zlotogora-Ogur/ Rosselli-Guglielmetti syndrome, MIM $225000,{ }^{40}$ and ED Margarita type syndrome, MIM 225060 ${ }^{41}$ ), and retinal degeneration.

BIOLOGICAL-FUNCTIONAL FEATURES AND IDENTIFIED CAUSATIVE GENES

Causative genes included in this group present a specific pattern of expression, being located at the adherens junction/gap junction/ apicolateral membrane domain and probably devoted to organisation of polarised apical plasma membrane domains and integrity/ stability of cell membrane/cytoskeleton compartment. The underlying pathogenetic mechanism is an abnormal function of structural proteins, basically required for the correct and normal formation of ectodermal derivatives.

Connexin 30, a gap junction protein highly expressed in skin and brain, is mutated in Clouston disease. ${ }^{42}$ Gap junction proteins have been reported to be involved in cooperation between cells, growth control, and regulation of development. ${ }^{434}$ Interestingly, a single point mutation in the same gene causes non-syndromic autosomal dominant deafness, ${ }^{45}$ while mutations in other connexins have been found to cause syndromic palmoplantar keratoderma and deafness or erythrokeratodermia variabilis. ${ }^{46}{ }^{47}$ On the basis of these data, we think that connexins are good candidate genes for EDs in which either hyperkeratosis/palmoplantar keratoderma or deafness are present.

The plakophilin 1 (PKP1) protein is altered in patients with $\mathrm{ED} /$ skin fragility syndrome. ${ }^{48} 49$ It is a major accessory desmosomal plaque protein. PKP1 is a member of the plakoglobulin $/ \beta$-catenin/armadillo family,${ }^{50}$ has a fundamental role in cell to cell adhesion, and may act as a linker protein between the adherens junction, desmosomes, and cornified envelope in the apico-lateral plasma membrane of epithelial cells. ${ }^{51}{ }^{52}$ The biological importance of PKP1 in maintaining the integrity/stability of the cell membrane/cytoskeleton compartment is proven by the demonstration, in cells from affected patients, of defective cell to cell interaction and abnormal distribution of keratin filaments, which are disorganised and do not participate in cytoskeleton formation. ${ }^{48}$

The poliovirus receptor gene (PVRL) is mutated in some forms of ED associated with cleft lip/palate (CLPED1). ${ }^{53}$ It encodes an immunoglobulin-like membrane receptor (nectin 1), which binds a scaffold protein with PDZ domains (afadin), ${ }^{54}$ and ponsin (nectin/ afadin/ponsin complex, NAP system) ${ }^{55}$ and is located in the apico-lateral membrane domain near the adherens junction compartment. ${ }^{56}$ NAP system has a central importance in maintenance of cell membrane stability and integrity through binding of afadin to actin and the cortical cytoskeleton and through binding of ponsin to vinculin and possible linkage of either these two and nectin to the cadherincatenin system. ${ }^{55-58}$ It also has a specific role in coordinating an array of signalling and cytoskeletal proteins. Owing to the presence of PDZ domains, afadin is likely to form heteromultimeres among different structures and to be closely anchored to other plasma membrane associated proteins. ${ }^{59}{ }^{60}$ Nectin 1 has a primary role in triggering an intracellular signalling cascade devoted to a correct integration of cell-cell contacts, cell morphology, and the disposition and organisation of plasma membrane domains.

We decided to include in this group EDs with retinal degeneration as a major clinical sign. Some forms of syndromic retinitis pigmentosa/retinal degeneration associated with deafness (see Usher type 1C syndrome) are the result of mutations in PDZ proteins like harmonin. ${ }^{61} \mathrm{PDZ}$ proteins play a central role in the organisation of protein complexes in plasma membrane domains and in cell junction formation. As discussed earlier, afadin is also a PDZ protein and is involved in the formation of the NAP system and coordination and transduction of the nectin 1 signal inside the intracellular compartment. ${ }^{55-58}$ We consider afadin and other PDZ proteins good candidate genes for EDs included in group 2 and in particular for those associated with retinal degeneration.

\section{Conclusion and future perspectives}

This classification allows a different approach to the patient affected with any form of ED by using major clinical features to guide the physician to a grouping by underlying mechanisms. We believe that this approach to EDs may also help researchers to find new candidate genes using "key" clinical signs to guide molecular investigation. This kind of approach may also be applicable to some other pathological conditions we decided not to include in our classification at this first attempt, because they did not fulfil the stringent inclusion criteria, 


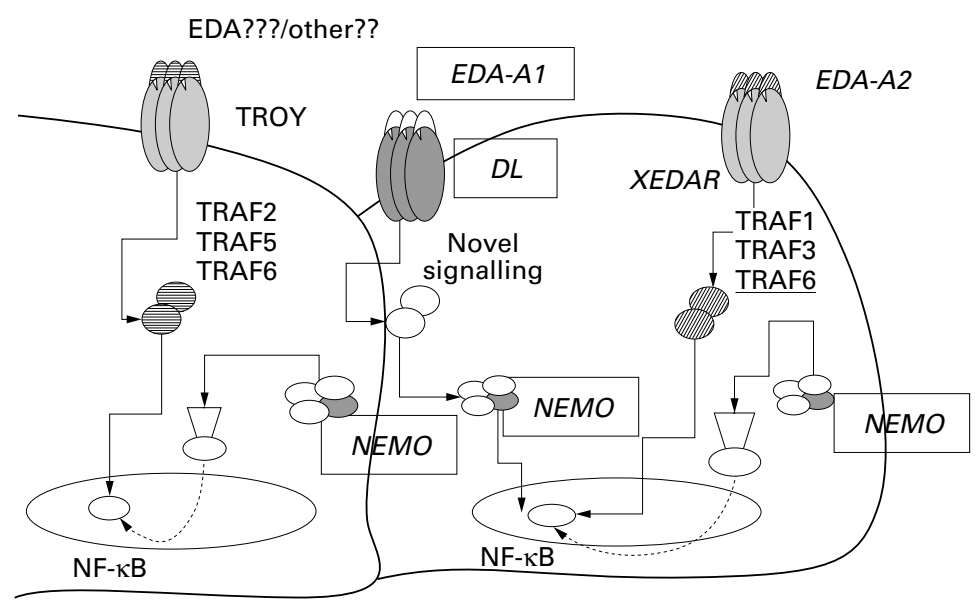

Figure 1 Intracellular pathway interactions in EDs. Group 1 molecular pathways converging on $N F-k B$. EDs causative genes are boxed. Some candidate genes for EDs are shown.

but are characterised by very similar "key signs" considered here, such as hyperkeratosis, keratoderma, or deafness. Our effort is a "work in progress" and some features discussed here may be not confirmed, in the future, by experimental findings. Nonetheless, we think that this is a useful tool in the recognition of pathological mechanisms in a confusing group of disorders.

In the EDs, different signalling pathways often converge on the same intracellular factors, or interact among them through common pathways of action, as exemplified by the role of NF-kB as a "key" molecule on which both EDA-A1/DL system and NEMO act (fig 1). Considering the augmented sensitivity to apoptosis in cells from subjects with IP, it would be interesting to test if the same phenomenon is present in both "tabby" and "dl" mice models. Recently, a novel orphan TNFR superfamily gene (TROY) has been identified, which shows high homology with $D L$ in both coding sequence and specific pathways of expression. ${ }^{62}$ In the mouse model, Troy has been mapped near the "waved coat" (wc) locus, a mutant type characterised by skin/hair anomalies, ${ }^{62}$ so we think that TROY is a good candidate gene for group 1 EDs. TROY also enhances NF-kB expression, but its function follows the known pathways of activation of $\mathrm{TNF}$ receptor associated factor (TRAF) 2, 5, and $6,{ }^{63}$ suggesting a double way of control of $\mathrm{NF}-\mathrm{kB}$ by DL/TROY receptors. We also speculate on a possible role of TROY as an additional receptor for EDA. If this was experimentally supported, EDA might activate downstream signals through two different pathways converging on the same nuclear factor (fig 1). However, TROY seems not specifically to bind EDA-A $1,{ }^{64}$ thus suggesting the existence of a novel ligand for this TNFR that has not been identified yet or, possibly, that TROY might bind a different EDA isoform. We think that another TNFR superfamily gene, the $\mathrm{X}$ linked ectodysplasin A2 receptor gene $(X E D A R),{ }^{64}$ is a good candidate gene for group 1 EDs. XEDAR shows a high homology with both DL and TROY TNFRs. ${ }^{64}$ XEDAR has been proven specifically to bind a second EDA isoform (EDA-A2) generated through the use of an alternative internal splice donor site of the $E D A$ gene. ${ }^{64}$ This latter is identical to EDA-A1 except for a two amino acid residue deletion in the $\mathrm{COOH}$-terminus domain. This two residue insert in EDA-A1 is thought to be on the surface of the protein in an area expected to interact with receptors. The signalling triggered by the EDA-A2/XEDAR binding system induces NF-kB activation. The cytoplasmic region of XEDAR binds TRAF1, TRAF3, and TRAF6; this last (and not other TRAFs) is specifically related to activation of NF-kB after binding with XEDAR, thus indicating that TRAF6 is probably a key adapter molecule in transducing XEDAR mediated NF-kB signal$\operatorname{ling}^{64}$ (fig 1). In light of these hypotheses, the regulation of NF-kB activity in preventing apoptosis and in regulating the development of highly specific structures may be one of the most frequent mechanisms in EDs aetiopathogenesis.

Some transcription factors can be considered good candidate genes for other EDs classified in group 1. As explained in our previous report, ${ }^{3}$ we think that $M S X 2$ is a good candidate for those conditions with craniosynostosis or parietal foramina as "key signs", such as Sensenbrenner disease (MIM 218330) and tricho-odonto-onychial dysplasia with frontal bone deficiency (MIM 275452).

Interesting molecular and functional interactions among proteins mutated in the EDs included in groups 1 and 2 and sharing as a common clinical finding cleft lip/palate may be hypothesised. CLPED1 syndromes are caused by mutations in the PVRL1 gene, which encodes a transmembrane receptor that is part of the NAP system and binds cytoskeleton and adherens junction domains. ${ }^{53-60}$ Some cases of EEC and AEC syndromes are caused by mutations in $p 63 .^{23}{ }^{24}$ The latter is likely to control transcription and expression of many genes, such as $\mathrm{MSX} 1$ and $\mathrm{SHH} .{ }^{23}$ Interestingly, mutations in these genes have been proven to cause different types of CLP associated, in the case of MSX1, with defects in epidermal derivatives. ${ }^{65}$ MSX1 is supposed to interact physically with another group 1 protein, DLX3, mutated in patients affected with tricho-dento-osseous syndrome. DLX3 is a potent transactivator of some cytoskeleton protein coding genes, such as profilaggrin. ${ }^{66-68}$ It would be interesting to test p63 or other transcription factors' activities in enhancing or regulating the expression of ectodermal structural proteins. Some other EDs show overlapping phenotypes between group 1 and group 2, such as EEM syndrome, in which both ectrodactyly and macular degeneration are present. ${ }^{69}$ Again, it is intriguing to hypothesise that this complex phenotype could result from somewhat altered regulation on $\mathrm{PDZ} /$ cytoskeleton protein transcription by p63, even directly or mediated by other(s) factor(s). Finally, we decided arbitrarily to include Rapp-Hodgkin disease in group 1 and preliminarily to consider it as the result of a defect of epithelial-mesenchymal interaction by referring to the description of an EEC child born to a mother with clinical findings characteristic of 
Rapp-Hodgkin disease. ${ }^{70}$ It would be possible to consider EEC/AEC and Rapp-Hodgkin disease as variable clinical expression of the same pathological entity. Although there is no evidence of $p 63$ mutations in patients affected with Rapp-Hodgkin disease, other genes could be involved in the pathogenesis of the EEC/ AEC/Rapp-Hodgkin disease clinical spectrum (genetic heterogeneity). Another genetic locus in $7 \mathrm{q}$, named EEC1, has been suggested ${ }^{71}$ by linkage analysis studies. Two members of the DLX family, named DLX5 and DLX6, are mapped in this region. Again, complex physical or functional interactions among different proteins (in the specific case of p63 and members of the DLX family) could be hypothesised in the pathogenesis of the EEC phenotype.

\section{Summary}

The proposed classification is a great advance in understanding the biological mechanisms of EDs pathogenesis. The clinical revision of EDs using the stringent criteria described here led us to exclude single case reports and some very well known described phenotypes which do not strictly fulfil the classical definition of ED.

This first attempt at genotype-phenotype correlation in EDs has taught us that both clinical and molecular data can help in defining each single patient. Molecular interactions and pathological mechanisms can explain the many clinical signs, variability in severity, associated malformations, and overlap seen in some ED patients. Conversely, the accurate definition of "key signs" can aid researchers in an attempt to find new candidate ED genes.

We wish to thank Professor Virginia P Sybert for helpful discussion and for critical reading of the manuscript.

1 Thurnam J. Two cases in which the skin, hair and teeth were imperfectly developed. Proc $R$ Med Chir Soc London 1848;31:71-81.

2 Pinheiro M, Freire-Maia N. Ectodermal dysplasias: a clinical classification and a causal review. Am $\mathcal{f}$ Med Genet 1994;53:153-62.

3 Priolo M, Silengo M, Lerone M, Ravazzolo R. Ectodermal dysplasias: not only "skin" deep. Clin Genet 2000;58:41531.

4 Siegel MB, Potsic WP. Ectodermal dysplasia: the otolaryngologic manifestations and management. Int $\mathcal{F}$ Pediatr Otorhinolaryngol 1990;19:265-71

5 Masse JF, Perusse R. Ectodermal dysplasia. Arch Dis Child 1994;71:1-2.

6 Clarke A. Hypohidrotic ectodermal dysplasia. 7 Med Genet 1987;24:659-63.

7 Nakata M, Koshiba H, Eto K, Nance WE. A genetic study of anodontia in X-linked hypohidrotic ectodermal dysplasia. Am f Hum Genet 1980;32:908-19.

8 Dhanrajani PJ, Jiffry AO. Management of ectodermal dysplasia: a literature review. Dent Update 1998;25:73-5.

9 Bertolino AP, Freedberg IM. Disorders of epidermal Bertolino AP, Freedberg IM. Disorders of epidermal
appendages and related disorders. In: Fitzpatrick TB, Eisen appendages and related disorders. In: Fitzpatrick TB, Eisen AZ, Wolff K, Freedberg IM, Austen KF, eds. Dermatology
in general medicine. 4th ed. New York: McGraw-Hill, 1993: in general

10 Baden HP, Kvedar JC. Disorders of epidermal appendages and related disorders. In: Fitzpatrick TB, Eisen AZ, Wolff $\mathrm{K}$, Freedberg IM, Austen KF, eds. Dermatology in general medicine. 4th ed. New York: McGraw-Hill, 1993:696-709.

11 Sirinavin C, Trowbridge AA. Dyskeratosis congenita clinical features and genetic aspects. Report of a family and review of the literature. F Med Genet 1975;12:339-54.

12 Baere JM, Nevin NC, Froggatt P, Kernohan DC, Allen IV. Atypical erythrokeratoderma with deafness, physical retar308-14.

$13 \mathrm{http} / /$ www.ncbi.nlm.nih.gov/entrez/query.fcgi?db=OMIM

14 Turnpenny PD, Dean JC, Auchterlonie IA, Johnston AW. Cardiofaciocutaneous syndrome with new ectodermal manifestations. F Med Genet 1992;29:428-9.

15 Vennos EM, Collins M, James WD. Rothmund-Thomson syndrome: review of the world literature. I Am Acad Dermatol 1992;27:750-62.
16 Price VH, Odom RB, Ward WH, Jones FT. Trichothiodystrophy: sulfur-deficient brittle hair as a marker for a neuroectodermal symptom complex. Arch Dermatol 1980;116:1375-84

17 Reed WB, Lopez DA, Landing BH. Clinical spectrum of anhidrotic ectodermal dysplasia. Arch Dermatol 1970;102: 134-43.

18 Baala L, Hadj Rabia S, Zlogotora J, Kabbaj K, Chhoul H, Munnich A, Lyonnet S, Sefiani A. Both recessive and autosomal dominant forms of anhidrotic/hypohidrotic ectodermal dysplasia map to chromosome 2q11-q13. Am f Hum Genet 1999;64:651-3.

19 Munoz F, Lestringant G, Sybert V, Frydman M, Alswaini A, Frossard PM, Jorgenson R, Zonana J. Definitive evidence Frossard PM, Jorgenson R, Zonana J. Definitive evidence
for an autosomal recessive form of hypohidrotic ectodermal dysplasia clinically indistinguishable from the more comdysplasia clinically indistinguishable from the more com-
mon X-linked disorder. Am $₹$ Hum Genet 1997;61:94-100.

20 Smahi A, Courtois G, Vabres P, Yamaoka S, Heuertz S, Munnich A, Israel A, Heiss NS, Kauck SM, Kioschis P, Wiemann S, Poustka A, Esposito T, Bardaro T, Gianfranc-
esco F, Ciccodicola A, D'Urso M, Woffendin H, Jankis T, esco F, Ciccodicola A, D'Urso M, Woffendin H, Jankis T,
Donnai D, Stewart H, Kenwrick SJ, Aradhya S, Yamagata T, Levy M, Lewis RA, Nelson DL. Genomic rearrangement in NEMO impairs NF-kappaB activation and is a cause of incontinentia pigmenti. The International Incontinentia Pigmenti (IP) Consortium. Nature 2000;25:405.

21 Zonana J, Elder ME, Schneider LC, Orlow SJ, Moss C, Golabi M, Shapira SK, Farndon PA, Wara DW, Emmal SA Ferguson BM. A novel X-linked disorder of immune deficiency and hypohidrotic ectodermal dysplasia is allelic to incontinentia pigmenti and due to mutations in IKKgamma (NEMO). Am f Hum Genet 2000;67:1555-62.

22 Doffinger R, Smahi A, Bessia C, Geissmann F, Feinberg J, Durando A Bodemer C, Kenwrick S, Dupuis-Girod S, Blanche S, Wood P, Hady Rabia S, Headon D, Overbeek PA, Le Deist F, Holland SM, Belani K, Kumararatne DS, Fischer A, Shapiro R, Conley ME, Reimund E, Kalhoff H,
Abinun M, Munnich A, Israel A, Courtois G, Casanova JL. $\mathrm{X}$-linked anhidrotic ectodermal dysplasia with immunodeficiency is caused by impaired NF-kB signaling. Nat Genet 2001;27:277-85

23 Celli J, Duijf P, Hamel BCJ, Bamshad M, Kramer B, Smits AP, Newbury-Ecob R, Hennekam RCM, van Buggenhout G, van Hearingen A, Woods CG, van Essen AJ, de Waal R, Vriend G, Haber DA, Yang A, McKeon F, Brunner HG, van Bakhoven $\mathrm{H}$. Heterozygous germline mutations in the
p53 homolog p63 are the cause of EEC syndrome. Cell 1999;99:143-53.

24 Van Bokhoven H, McGrath JA, Duijf P, Celli J, Hamel BCJ, de Waal R, Brunner HG. P63 mutations in the EEC, HayWells, ADULT syndromes and in split hand/foot malformation reveals a genotype-phenotype correlation. 50th Annual Meeting of the American Society of Human Genetics. Philadelphia, Pennsylvania, 3-7 October 2000: program No 149.

25 Price JA, Bowden DW, Wright JT, Pettenati MJ, Hart TC. Identification of a mutation in DLX3 associated with tricho-dento-osseous (TDO) syndrome. Hum Mol Genet 1998;7:563-9.

26 Ruiz-Perez VL, Ide SE, Strom TM, Lorenz B, Wilson D, Woods K, King L, Francomano C, Freisinger P, Spranger S, Marino B, Dallapiccola B, Wright M, Meitinger T, Polymeropoulos M, Goodship J. Mutations in a new gene in Ellis-van Creveld syndrome and Weyers acrodental dys-
ostosis. Nat Genet 2000;24:283-6.

7 Soekarman D, Fryns JP. Hypohidrotic ectodermal dysplasia, central nervous system malformation, and distinct facial features: confirmation of a new entity? $f$ Med Genet 1993;30:245-7.

28 Pike MG, Baraitser M, Dinwiddie E, Atherton DJ. A distinctive type of hypohidrotic ectodermal dysplasia featuring hypothyroidism. $\mathcal{F}$ Pediatr 1986;108:109-11.

29 Kere J, Srivastava AK, Montonen O, Zonana J, Thomas N, Ferguson B, Munoz F, Morgan D, Clarke A, Baybayan P, Chen EY, Saarialho-Kere U, de la Chapelle A, Schlessinger D. X-linked anhidrotic (hypohidrotic) ectodermal dysplasia is caused by mutation in a novel transmembrane protein. Nat Genet 1996;13:409-16.

30 Monreal AW, Ferguson BM, Headon DJ, Street SL, Overbeek PA, Zonana J. Mutations in the human homologue of mouse dl cause autosomal recessive and dominant hypohidrotic ectodermal dysplasia. Nat Genet 1 Headon DJ, Overbeek A. Involvement of a novel Tnf recep-
tor homologue in hair follicle induction. Nat Genet tor homologue

32 Ezer S, Bayes M, Elomaa O, Schlessinger D, Kere J. Ectodysplasin is a collagenous trimeric type II membrane protein with a tumor necrosis factor-like domain and co-localizes with cytoskeletal structures at lateral and apical surfaces of cells. Hum Mol Genet 1999;8:2079-86.

33 Srivastava AK, Pispa J, Hartung AJ, Du Y, Ezer S, Jenks T, Shimada T, Pekkanen M, Mikkola ML, Thesleff L, Kere J, Schlessinger D. Tabby phenotype is caused by mutation in mouse homologue of EDA gene that reveals novel mouse and human exons and encodes a protein (ectodysplasin-A) with collagenous domains. Proc Natl Acad Sci USA 1997;94:13069-74.

34 Mikkola ML, Pispa J, Pekkanen M, Paulin L, Nieminen P, Kere J, Thesleff I. Ectodysplasin, a protein required for epithelial morphogenesis, is a novel TNF homologue and promotes cell-matrix adhesion. Mech Dev 1999;88:133-46.

35 Kumar A, Eby MT, Sinha S, Jasmin A, Chaudhary PM. Ectodermal dysplasia receptor activates the nuclear factor 
kappa B, c-Jun N-terminal kinase and cell death pathways and binds ectodysplasin A. F Biol Chem 2001;276:2668-77.

36 May MJ, D'Acquisto F, Madge LA, Glockner J, Pober JS Ghosh S. Selective inhibition of NF-kappa B activation by a peptide that blocks the interaction of NEMO with the IkappaB kinase complex. Science 2000;289:1550-4.

37 Jain A, Ma CA, Liu S, Brown M, Cohen J, Strober W. Specific missense mutations in NEMO result in hyper-IgM syndrome with hypohidrotic ectodermal dysplasia. Nat Immunol 2001;2:223-8.

38 Ishida Y, Hadano S, Nagayama T, Tomiyasu H, Wakasa K, Ikeda J. Isolation and characterization of 21 novel expressed DNA sequences from the distal region of human chromosome 4p. Genomics 1994;22:302-12.

39 Clouston RH. A hereditary ectodermal dystrophy. Can Med Assoc f 1929;21:18-31

40 Zlogotora J, Zilberman Y, Tenebaum A, Wexler MR. Cleft lip and palate, pili torti, malformed ears, partial syndactyly of fingers and toes, and mental retardation: a new syndrome? 7 Med Genet 1987;24:291-3.

41 Bustos T, Simosa V, Pinto-Cisternas J, Abramovits W, Jolay L, Rodriguez L, Fernandez L, Ramela M. Autosomal L, Rodriguez L, Fernandez L, Ramela M. Autosomal recessive ectodermal dysplasia. An undescribed dysplasia/ malform

42 Lamartine J, Essenfelder MG, Kibar Z, Lanneluc I, Callouet E, Laoudj D, Lemaitre G, Hand C, Hayflick SJ, Zonana J, Antonarakis S, Radhakrishna U, Kelsell DP, Christianson AL, Pitaval A, Der Kaloustian V, Fraser C, Blanchet-Bardon C, Rouleau GA, Waksman G. Mutations in GJB6 cause hidrotic ectodermal dysplasia. Nat Genet 2000;26:142-4

43 Rabionet R, Gasparini P, Estivill X. Molecular genetics of hearing impairment due to mutations in gap junction genes encoding beta connexins. Hum Mutat 2000;16:190-202.

44 Willecke K, Hennekam H, Dahl E, Jungbluth S, Haynkes R. The diversity of connexin genes encoding gap junctional proteins. Eur f Cell Biol 1991;56:1-7.

45 Grifa A, Wagner CA, D'Ambrosio L, Melchionda S, Bernardi F, Lopez-Bigas N, Rabionet R, Arbones M, Della Bernardi F, Lopez-Bigas N, Rabionet R, Arbones M, Della Mutations in $G 7 B 6$ cause nonsyndromic autosomal domiMutations in G尹B6 cause nonsyndromic autosomal domi-

nant deafness at DNFA3 locus. Nat Genet 1999;23:16-18.
Maestrini E, Korge BP, Ocana-Sierra J, Calzolari E, Cambi-

Maestrini E, Korge BP, Ocana-Sierra J, Calzolari E, Cambi-
aghi S, Scudder PM, Hovnanian A, Monaco AP, Munro aghi S, Scudder PM, Hovnanian A, Monaco AP, Munro CS. A missense mutation in connexin 26 , D66H, causes winkel's syndrome) in three unrelated families. Hum $\mathrm{Mol}$ Genet 1999;8:1237-43A

47 Richard G, Smith LE, Bailey RA, Itin P, Hohl D, Epstein DH, DiGiovanna JJ, Compton JG, Bale SJ. Mutations in the human connexin gene $G 7 B 3$ cause erythrokeratodermia variabilis. Nat Genet 1998;20:366-9.

48 McGrath JA, McMillan JR, Shemanko CS, Runswick SK, Leigh IM, Lane EB, Garrod DR, Eady RA. Mutations in the plakophilin 1 gene result in ectodermal dysplasia/skin fragility syndrome. Nat Genet 1997;17:240-4

49 Whittock NV, Haftek M, Angoulvant N, Wolf F, Perrot $\mathrm{H}$, Heady RA, McGrath JA. Genomic amplification of the Heady RA, McGrath JA. Genomic amplification of the human plakophilin 1 gene and detection of a new mutation in ectodermal dysplasia/skin

50 Hatzfeld M, Kristjansson GI, Plessmann U, Weber W. Band 6 protein, a major constituent of desmosomes from stratified epithel tigene family. F Cell Biol 1994;107:2259-70.

51 Heid HW, Schmidt A, Zimbelmann R, Schafer S, Winter-Simanowski S, Stumpp S, Keith M, Figge U, Schnolzer M, Franke WW. Cell type-specific desmosoma plaque protein of the plakoglobulin family: plakophilin 1 (band 6 protein). Differentiation 1994;58:113-31.

52 Moll I, Kurzen H, Langbein L, Franke WF. The distribution of the desmosomal protein, plakophilin 1, in human skin and skin tumors. F Invest Dermatol 1997;108:139-46.

53 Suzuki K, Hu D, Bustos T, Zlogotora J, Richeri-Costa A, Helms JA Spritz RA. Mutations of PVRL1, encoding a cell-cell adhesion molecule/herpesvirus receptor, in cleft lip/palate-ectodermal dysplasia. Nat Genet 2000;25:427lip/p

54 Takahashi K, Nakanishi H, Miyahara M, Mandai K, Satoh K, Satoh A, Nishioka H, Aoki J, Nomoto A, Mizoguchi A Takai Y. Nectin/PRR: an immunoglobulin-like cell adhesion molecule recruited to cadherin-based adherens junctions through interaction with Afadin, a PDZ domaincontaining protein. F Cell Biol 1999;145:539-49.
55 Mandai K, Nakanishi H, Satoh A, Takahashi K, Satoh K, Nishioka H, Mizoguchi A, Takai Y. Ponsin/SH3P12: an 1 -afadin- and vinculin-binding protein localized at cell-cell and cell-matrix adherens junctions. F Cell Biol 1999;144: 1001-17.

56 Ikeda W, Nakanishi H, Miyoshi J, Mandai K, Ishizaki H, Tanaka M, Togawa A, Takahashi K, Nishioka H, Yoshida H, Mizoguchi A, Nishikawa S, Takai Y. Afadin: a key molecule essential for structural organization of cell-cell junctions of polarised epithelia during embryogenesis. $\mathcal{f}$ Cell Biol 1999;146:1117-32.

57 Asakura T, Nakanishi H, Sakisaka T, Takahashi K, Mandai K, Nishimura M, Sasaki T, Takai Y. Similar and differential behaviour between the nectin-afadin-ponsin and cadherincatenin systems during the formation and disruption of the polarized junctional alignment in epithelial cells. Genes Cells 1999;4:573-81.

58 Tachibana K, Nakanishi H, Mandai K, Ozaki K, Ikeda W, Yamamoto Y, Nagafuchi A, Tsukita S, Takai Y. Two cell adhesion molecules, nectin and cadherin, interact through their cytoplasmic domain-associated proteins. F Cell Biol 2000;150:1161-76.

59 Fannings AS, Anderson JM. PDZ proteins: fundamental building blocks in the organization of protein complexes at the plasma membrane. F Clin Invest 1999;103:767-72.

60 Mandai K, Nakanishi H, Satoh A, Obaishi H, Wada M, Nishioka H, Itoh M, Mizoguchi A, Aoki T, Fujimoto T, Matsuda Y, Tsukita S, Takai Y. Afadin: a novel actin filament-binding protein with one PDZ domain localized at cadherin-based cell-to-cell adherens junction. $f$ Cell Biol 1997;139:517-28.

61 Verpy E, Leibovici M, Zwaenepoel I, Liu XZ, Gal A, Salem N, Mansour A, Blanchard S, Kobayashi I, Keats BJB, Slim $\mathrm{R}$, Petit C. A defect in harmonin, a PDZ domaincontaining protein expressed in the inner ear sensory hair cells, underlies Usher syndrome type 1C. Nat Genet 2000; 26:51-6.

62 Kojima T, Morikawa Y, Copeland NG, Gilbert DJ, Jenkins NA, Senba E, Kitamura T. TROY, a newly identified member of the tumor necrosis factor receptor superfamily, exhibits a homology with Edar and is expressed in embryonic skin and hair follicles. F Biol Chem 2000;275:20742-7.

63 Eby MT, Jasmin A, Kumar A, Sharma K, Chaundhary PM. TAJ, a novel member of the tumor necrosis factor receptor family, activates the c-Jun N-terminal kinase pathways and mediates caspase-independent cell death. 7 Biol Chem 2000;275:15336-42.

64 Yang M, Wang LC, Hymowitz SG, Schilbach S, Lee J, Goddard A, de Vos AM, Gao WQ, Dixit VM. Two-amino acid molecular switch in an epithelial morphogen that regulates binding to two distinct receptors. Science 2000;290:523-7.

65 van den Boogaard MJH, Dorland M, Beemer FA, Ploos van Amstel HK. MSX1 mutation is associated with orofacial clefting and tooth agenesis in humans. Nat Genet 2000;24: 342-3.

66 Feledy JA, Morasso MI, Jang SI, Sargent TD. Transcriptional activation by the homeodomain protein Distal-less 3 . Nucleic Acids Res 1999;27:764-70.

67 Zhang H, Hu G, Wang H, Sciavolino P, Her N, Shen MM, Abate-She A. Heterodimerization of Msx and Dlx homeoproteins results in functional antagonism. Mol Cell Biol 1999;17:2920-32

68 Morasso MI, Markova NG, Sargent TD. Regulation of epidermal differentiation by a Distal-less homeodomain gene. f Cell Biol 1996;135:1879- 87.

69 Ohdo S, Hirayama K, Terawaki T. Association of ectodermal dysplasia, ectrodactyly and macular dystrophy. The EEM syndrome. 7 Med Genet 1983;20:52-7.

70 Moerman P, Fryns JP. Ectodermal dysplasia, Rapp-Hodgkin type in a mother and severe ectrodactyly-ectodermal dysplasia-clefting syndrome (EEC) in her child. $\mathrm{Am} \mathrm{F} \mathrm{Med}$ Genet 1996;63:479-81

71 Scherer SW, Poorkaj P, Massa H, Soder S, Allen T, Nunes M, Geshuri D, Wong E, Belloni E, Little S, Zhou L, Becker , Kere J, Ignatius J, Niikawa N, Fukushiima Y, Hasegawa T, Weissenbach J, Boncinelli E, Trask B, Tsui LC, Evans JP. Physical mapping of the split hand/split foot locus on chromosome 7 and implication in syndromic ectrodactyly. Hum Mol Genet 1994;3:1345-54. 